\title{
SYNTHESIS OF ORGANIC NITROGEN AND CHLOROPHYLL BY NITZSCHIA CLOSTERIUM
}

\author{
By H. W. Harvey, F.R.S. \\ The Plymouth Laboratory
}

(Text-figs. I-4)

When cells of Chlorella are grown in a medium containing a limiting quantity of nitrate or ammonia as nitrogen source, photosynthesis and cell division continue after all the available nitrogen in the medium has been abstracted by the growing plants. The cells become nitrogen-deficient. When kept in darkness with added nitrate these nitrogen-deficient cells synthesize a considerable quantity of organic nitrogen (Ketchum, 1939) and use more oxygen in respiration than when kept in darkness without added nitrogen (Myers \& Cramer, I948, p. I06). Growing in darkness with glucose as a carbon source, they use more oxygen when supplied with nitrate than when supplied with ammonium, and even more carbon dioxide is evolved (Cramer \& Myers, I948, fig. I), indicating a greater break-down of carbohydrate to supply the necessary energy for synthesis of organic nitrogen compounds from nitrate than from ammonium.

These observations of nitrogen metabolism in Chlorella have suggested that diatoms, and phytoplankton generally, may become nitrogen-deficient when the nitrogen source is reduced to very low concentrations, such as occur in the sea during summer, and in consequence are able to absorb and build up organic nitrogen during the night (Harvey, I945, p. 133). In order to obtain more information concerning nitrogen metabolism in phytoplankton the following experiments were made.

The marine diatom Nitzschia closterium var. minutissima, free from bacteria, was inoculated into autoclaved sea water of $26 \%$ salinity enriched with phosphate, iron, manganese and a limiting quantity of nitrate or nitrite or ammonia. The cultures were aerated and illuminated continuously by fluorescent lamps. Under these conditions, after a short lag period depending upon the physiological state of the inoculum, exponential growth proceeds, slowing after the nitrogen source in solution has been absorbed by the cells and stopping some 2 days later, when the cells attain a 'stationary state', being fully deficient in nitrogen.

When these 'stationary' deficient cells were stored in darkness for periods up to $\mathrm{I} 2 \mathrm{O} \mathrm{hr}$., there was no significant change in cell numbers, optical density (turbidity) of the culture, content of cellular nitrogen or of chlorophyll. On the other hand, when illumination was continued a slow decrease in chlorophyll occurred. 
In order to follow the rate at which organic nitrogen is synthesized by nitrogen-deficient Nitzschia cells in the dark when supplied with nitrate, ammonia or nitrite, or mixtures of these, four experiments have been made. Samples of the culture after adding a nitrogen source and storing in the dark were withdrawn at intervals and centrifuged, the deposit washed with sea water, and the cellular nitrogen determined by a micro-Kjeldahl method (Harvey, I95I). The results are shown in Table I and Figs. I and 2 (Exps. 1-4).

\section{Table I. Synthesis of Organic Nitrogen by Nitrogen-Deficient NITZSCHIA IN THE Dark}
Nitrogen added at start of storage period ( $\mu \mathrm{g} . / \mathrm{ml}$.)

\author{
$4 \mu \mathrm{g} . \mathrm{NH}_{4}-\mathrm{N}$ \\ $4 \mu \mathrm{g} . \mathrm{NO}_{3}-\mathrm{N}$ \\ $4 \mu \mathrm{g} . \mathrm{NO}_{2}-\mathrm{N}$ \\ $4 \mu \mathrm{g}$. $\mathrm{NO}_{3}+4 \mu \mathrm{g} . \mathrm{NO}_{2}-\mathrm{N}$
}

$8 \mu \mathrm{g} . \mathrm{NH}_{4}-\mathrm{N}$
$8 \mu \mathrm{g} . \mathrm{NO}_{3}-\mathrm{N}$
$8 \mu \mathrm{g} . \mathrm{NH}_{4}-\mathrm{N}+8 \mu \mathrm{g} . \mathrm{NO}_{3}-\mathrm{N}$

$8 \mu$ g. $\mathrm{NH}_{4}-\mathrm{H}$

$8 \mu \mathrm{g} . \mathrm{NO}_{3}-\mathrm{N}$

$4 \mu \mathrm{g}$. $\mathrm{NO}_{2}-\mathrm{N}$

$4 \mu \mathrm{g} . \mathrm{NO}_{3}-\mathrm{N}+4 \mu \mathrm{g} . \mathrm{NO}_{2}-\mathrm{N}$
Increase as percentage of initial quantity of organic nitrogen present in I ml. of culture after storage in dark Exp. 1 Cells in I ml. culture contained $0.75 \mu \mathrm{g} . \mathrm{N}$ and had been 3-4 days in stationary phase

\begin{tabular}{|c|c|c|}
\hline $\begin{array}{c}\text { After } 24 \mathrm{hr} . \\
230\end{array}$ & $\begin{array}{c}\text { After } 48 \mathrm{hr} . \\
240\end{array}$ & After $120 \mathrm{hr}$. \\
\hline I25 & I40 & I40 \\
\hline Not significant & I7 & $67^{\star}$ \\
\hline I25 & 125 & 125 \\
\hline $\begin{array}{c}\operatorname{Exp} .2 \mathrm{Ce} \\
2 \cdot 0 \mu \mathrm{g} . \mathrm{N}\end{array}$ & $\begin{array}{l}\text { I ml. culture } \\
\text { lays in stationa }\end{array}$ & $\begin{array}{l}\text { atained } \\
\text { phase }\end{array}$ \\
\hline $\begin{array}{c}\text { After } 24 \mathrm{hr} \text {. } \\
127 \\
70\end{array}$ & $\begin{array}{c}\text { After } 48 \mathrm{hr} \text {. } \\
127 \\
8 \mathrm{~T}\end{array}$ & $\begin{array}{c}\text { After I20 hr. } \\
\text { I20 } \\
85\end{array}$ \\
\hline I30 & 129 & - \\
\hline
\end{tabular}

Exp. 3 Cells in I ml. contained $3.0 \mu \mathrm{g}$. N, 6 days in stationary phase

$\begin{array}{ccc}\text { After } 24 \mathrm{hr} . & \text { After } 48 \mathrm{hr} . & \\ \text { I47 } & \text { I } 43 & - \\ 73 & 73 & - \\ \text { I0 } & \text { 13 } & - \\ 73 & 76 & -\end{array}$

Exp. 4 Cells in I ml. contained $2.0 \mu \mathrm{g} \mathrm{N}$, $36 \mathrm{hr}$. in stationary phase

$\begin{array}{ccc}\text { After I9 hr. } & \text { After } 43 \mathrm{hr} . & \text { After } 96 \mathrm{hr} . \\ \text { I62 } & \text { I66 } & - \\ \text { I00 } & \text { I38 } & \text { I50 } \\ \text { I45 } & \text { I67 } & -\end{array}$

$$
\begin{aligned}
& 4 \mu \text { g. } \mathrm{NH}_{4}-\mathrm{N} \\
& 4 \mu \text { g. } \mathrm{NO}_{3}-\mathrm{N} \\
& 4 \mu \mathrm{g} . \mathrm{NH}_{4}-\mathrm{N}+4 \mu \mathrm{g} . \mathrm{NO}_{3}-\mathrm{N}
\end{aligned}
$$

* Analysis of the culture medium showed a loss in nitrite- $\mathrm{N}$ similar to the gain in organic-N by the diatom cells.

In order to determine which source was utilized when nitrogen-deficient Nitzschia was stored in darkness after the addition of both nitrate and ammonium, the following experiment was made.

Exp. 5. Nitzschia was grown with nitrate as nitrogen source. After 3 days in the stationary state, the culture was divided, additions made and the two suspensions stored $48 \mathrm{hr}$. in darkness. The ammonia in each (cells included) was then determined by microdiffusion (Conway, I940). 


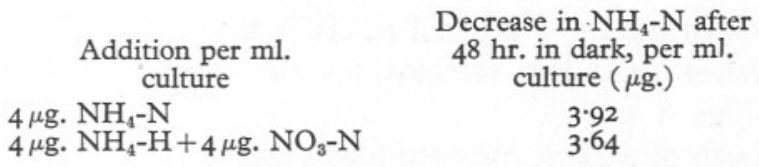

The experiment was repeated using a culture of $\mathrm{N}$-deficient cells which had been grown with ammonium as the limiting nitrogen source.

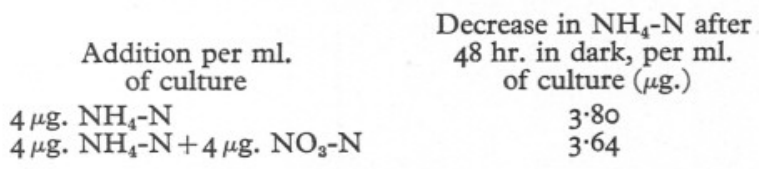

The experiment shows preferential synthesis from ammonia in darkness. It had been found previously (Harvey, 1940) that a mixed community of marine diatoms utilized ammonia in preference to nitrate when grown in light.

In Exps. 1 and 3 there was only a I 7 and a $13 \%$ increase in cellular nitrogen after $48 \mathrm{hr}$. dark-storage with added nitrite. It seemed possible that this small increase was not due to synthesis from nitrite, as such, but from ammonia or nitrate to which some of the added nitrite had been converted in the external medium, by oxidation or by reduction due to an extracellular enzyme. In order to explore this possibility the following experiment was made.

Exp. 6. Nitzschia was grown with nitrite as a limiting nitrogen source until the cells were in the stationary phase. The cells in I ml. culture then contained $2 \mu \mathrm{g}$. nitrogen. The culture was divided, to one portion nitrite only was added, to the other portion both nitrite and ammonium sulphate. After storage for $48 \mathrm{hr}$. in darkness, the nitrite in both portions was estimated with the following result:

$$
\begin{array}{cc}
\text { Addition per ml. } & \begin{array}{c}
\text { Decrease in nitrite } \\
\text { of culture }
\end{array} \\
\text { concentration after dark } & \text { storage (\%) } \\
2 \mu \text { g. } \mathrm{NO}_{2}-\mathrm{N} \text { only } & 25 \\
2 \mu \text { g. } \mathrm{NO}_{2}-\mathrm{N}+2 \mu \text { g. } \mathrm{NH}_{4}-\mathrm{N} & 2.5
\end{array}
$$

Since there was no significant change in concentration where ammonium was also added, it seems unlikely that nitrite is oxidized or reduced in the medium before being slowly absorbed and utilized in darkness by the nitrogendeficient cells, unless nitrite-oxidizing or reducing bacteria had entered the culture during the $48 \mathrm{hr}$. and had been inhibited by ammonia.

These dark-storage experiments point to the following conclusions:

(i) The presence of nitrate had little or no effect on organic nitrogen synthesis from ammonia in the dark, ammonia being utilized in preference to nitrate (Exp. 5).

(ii) The presence of nitrite had little or no effect on the utilization of nitrate in the dark (Exps. 1 and 3).

(iii) The quantity of organic nitrogen synthesized in the dark, by the same number of nitrogen-deficient diatom cells, from ammonia-N was greater than from nitrate-N. This is presumably because more organic matter is lost by 
respiration when nitrate is utilized in order to provide the energy necessary for its reduction, and less remains for the synthesis of organic nitrogen (Exps. 1-4, Figs. I and 2).

(iv) Synthesis of organic nitrogen took place in the dark from either nitrate or ammonium by cells. which could utilize nitrite only very slowly during a period of $48 \mathrm{hr}$. or more (Exps. 1 and 3, Fig. I).

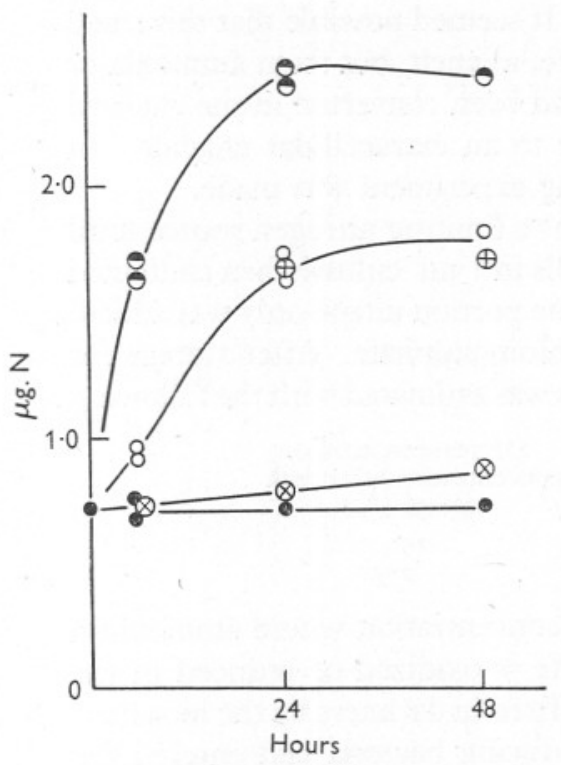

Fig. I

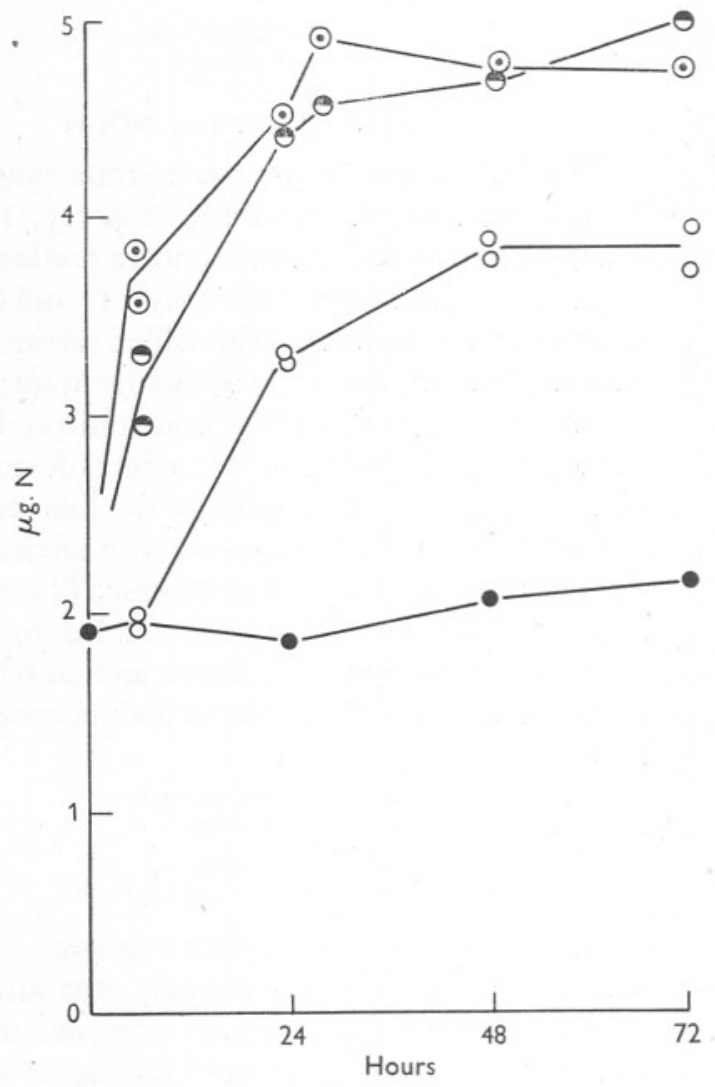

Fig. 2

Fig. I. Micrograms organic nitrógen found in the cells contained in a cubic centimetre of nitrogen-deficient culture when stored in the dark after additions of nitrate, ammonia and nitrite (Exp. I). $\odot, 4 \mu \mathrm{g} . \mathrm{NH}_{4}-\mathrm{N} ; \mathrm{O}, 4 \mu \mathrm{g}$. $\mathrm{NO}_{3}-\mathrm{N} ; \oplus, 4 \mu \mathrm{g}$. $\mathrm{NO}_{3}-\mathrm{N}+4 \mu \mathrm{g} . \mathrm{NO}_{2}$; $\otimes, 4 \mu \mathrm{g} . \mathrm{NO}_{2}-\mathrm{N}$; all added before storage in dark; $\bullet$, no addition.

Fig. 2. Micrograms of organic nitrogen found in the cells contained in a cubic centimetre of nitrogen-deficient culture when stored in the dark after additions of ammonia and nitrate. $\odot, 8 \mu \mathrm{g} . \mathrm{NH}_{4}-\mathrm{N} ; \odot, 8 \mu \mathrm{g} . \mathrm{NH}_{4}-\mathrm{N}+8 \mu \mathrm{g} . \mathrm{NO}_{3}-\mathrm{N} ; \bigcirc, 8 \mu \mathrm{g} . \mathrm{NO}_{3}-\mathrm{N}$; all added before storage in dark;, no addition.

A large number of observations have been made on the growth or division rate of this diatom at $17^{\circ} \mathrm{C}$. at a light intensity which was such that a variation of $\pm 30 \%$ had little effect. The cells were saturated with respect to light. 
After an initial lag, exponential growth proceeded as rapidly with nitrite or nitrate as with ammonium as nitrogen source-the number of cells doubling in $9-\mathrm{IO} \frac{1}{2} \mathrm{hr}$. (C. P. Spencer, private communication).

When deficient cells were stored in the dark with added ammonium, their nitrogen content doubled or more than doubled in Io hr. (Figs. I and 2). The experiments provide no evidence that light enhances the rate of synthesis from ammonium nitrogen.

When deficient cells were stored in the dark with added nitrate, the rate of synthesis was much less. In Exp. I, where the most rapid dark-synthesis was observed, some $18 \mathrm{hr}$. were required for the cells to double their nitrogen content. This suggests that light or some early product of photosynthesis may enhance the rate of synthesis from nitrate.

When deficient cells were stored in the dark with nitrite (Exps. 1,3 and 6) very little or no synthesis took place in Io $\mathrm{hr}$.

This shows that some transient product of photosynthesis, or light energy, enhances the synthesis of organic nitrogen from nitrite very considerably.

When deficient cells are supplied with nitrite and illuminated, growth in numbers does not start until after a lag period of several hours. In order to ascertain the effect of light during this period, an experiment was made in which deficient Nitzschia with added nitrite were stored both in darkness and in the light of a north window. The nitrite remaining was estimated.

After $5 \mathrm{hr}$. in the dark there was a barely significant decrease in nitrite in the culture, whereas after $5 \mathrm{hr}$. illumination a third of the nitrite- $\mathrm{N}$ had disappeared.

Why is nitrate absorbed and reduced to amino-nitrogen quickly in darkness while nitrite is not reduced, although nitrite is the most probable first step in the series of reactions by which nitrate nitrogen is converted to protein-nitrogen?

Besides nitrogen-deficient Nitzschia in darkness, neither the pulp of wheat roots (Burström, I946) nor the crown-gall tissue of sunflower (Ricker \& Gutsche, 1948) can utilize nitrite, whereas they can utilize nitrate.

As stated by Burström, for wheat roots, this is inexplicable if free nitrite is produced as the first step in the reduction of nitrate. He suggests that nitrate is first absorbed becoming firmly bound to cytoplasm, and then reduced to nitrite firmly bound to plasm colloid, no nitrite ions being set free.

Although this explanation can account for nitrite not being utilized by wheat roots or sunflower tissue, it cannot wholly account for deficient Nitzschia not using nitrite in the dark yet using it in the light.

For utilization of nitrite in the light it is necessary to postulate that some early transitory product of photosynthesis either directly reduces the nitrite ions to oxime- or amino-nitrogen, or, alternatively, combines with the nitrite ions and allows reduction to proceed by enzyme action.

If this postulate is correct, then it is possible that during reduction of nitrate in the dark (when respiration is increased) a similar transitory product 
is set free which enables nitrite, formed as an intermediate, to be further reduced to amino-nitrogen. Such would account for the behaviour of Nitzschia, wheat root and sunflower gall tissue, and bring the observed phenomena into line.

These speculations assume that nitrite is the first intermediate when nitrate is utilized. There is no direct evidence for this. Bonner (I950, p. 225), reviewing nitrate reduction by plants, writes 'it is entirely possible that in some cases the reduction of nitrate may proceed through other reactions than the series of steps to be expected on the basis of inorganic chemistry'. Thus there is the possibility that in darkness Nitzschia, wheat roots and sunflower gall tissue do not reduce added nitrate via nitrite, and that nitrite is only utilized when it can combine or react with early products of photosynthesis.

\section{Solubility of Organic Nitrogen Compounds Synthesized in Darkness}

The following experiment shows that three-quarters of the dark synthesized nitrogen is soluble, compared with one-fifth of the total nitrogen in nitrogendeficient cells.

Exp. 7. A culture of Nitzschia which had been stationary for $36 \mathrm{hr}$. was divided into four portions, to which additions were made as shown below. After $43 \mathrm{hr}$. in darkness, duplicate samples from each were centrifuged and the nitrogen in the cells determined. Also duplicate samples were centrifuged, resuspended in distilled water, heated for a few minutes in a boiling waterbath, again centrifuged and the nitrogen in the leached cells was determined.

\begin{tabular}{|c|c|c|c|}
\hline \multirow[b]{2}{*}{$\begin{array}{l}\text { Addition per ml. } \\
\text { of culture }\end{array}$} & \multicolumn{3}{|c|}{ Micrograms nitrogen in cells per ml. of culture } \\
\hline & $\begin{array}{c}\text { Cells } \\
\text { untreated }\end{array}$ & $\begin{array}{l}\text { After leaching cells } \\
\text { in hot water }\end{array}$ & $\begin{array}{c}\text { Soluble } \mathrm{N} \\
\text { (by difference) }\end{array}$ \\
\hline No addition & $r \cdot 96, r \cdot 97:$ mean $r \cdot 96$ & $I \cdot 59, r \cdot 63$ : mean $I \cdot 6 I$ & 0.35 \\
\hline $4 \mu \mathrm{g} . \mathrm{NH}_{3}-\mathrm{N}$ & $5 \cdot 15,5 \cdot 30:$ mean $5 \cdot 22$ & $2 \cdot 57,2 \cdot 91:$ mean $2 \cdot 74$ & $2 \cdot 48$ \\
\hline With $4 \mu \mathrm{g} . \mathrm{NO}_{3}-\mathrm{N}$ & $4.64,4.70:$ mean 4.67 & $2 \cdot 48, I \cdot 98:$ mean $2 \cdot 25$ & $2 \cdot 42$ \\
\hline $\begin{array}{l}4 \mu \mathrm{g} . \mathrm{NH}_{3}-\mathrm{N} \text { and } \\
4 \mu \mathrm{g} . \mathrm{NO}_{3}-\mathrm{N} \text { added }\end{array}$ & $5 \cdot 34,5 \cdot 27:$ mean $5 \cdot 30$ & $2.55,2.53:$ mean 2.54 & $2 \cdot 76$ \\
\hline
\end{tabular}

It is seen that the increase in organic nitrogen due to synthesis from ammonia or nitrate is largely in the form of water-soluble organic matter, while from the nitrogen-deficient control cells only I $\%$ dissolved.

$\begin{array}{ccc}\text { Nitrogen source } & \begin{array}{c}\text { Increase in insoluble, and in water-soluble, } \\ \text { nitrogen in cells per ml. of culture, due to } \\ \text { synthesis in dark }(\mu \mathrm{g} .)\end{array} \\ \text { added } & \text { Insoluble N } & \text { Soluble N } \\ \text { Ammonia } & 1.13 & 2.13 \text { or } 65 \% \\ \text { Nitrate } & 0.64 & 2.07 \text { or } 76 \% \\ \text { Both } & 0.93 & 2.4 \mathrm{I} \text { or } 72 \%\end{array}$




\section{Chlorophyll Synthesis}

During the course of the foregoing experiments it was noticed that the nitrogen-deficient cells became more heavily pigmented during storage in darkness with added nitrate or ammonia, and also that during the growth of a culture the cells became less heavily pigmented before growth in numbers ceased. These visual observations of the cells indicated that pigment synthesis was limited by the supply of available nitrogen to the plant, and that synthesis takes place in the dark if available nitrogen is added to the medium and synthesized by the cells.

These two aspects of pigment synthesis were examined in the following manner.

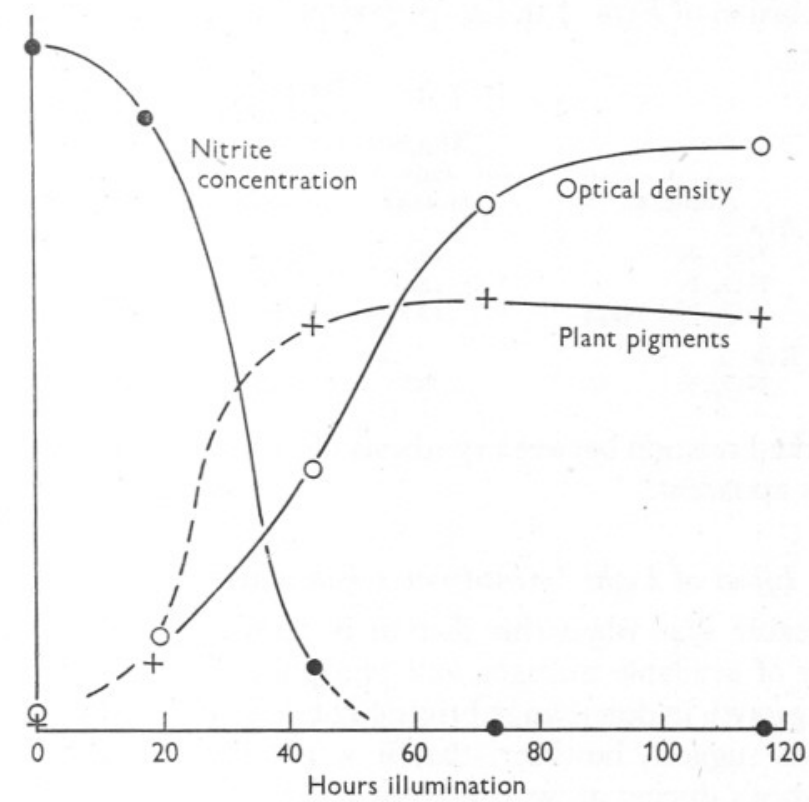

Fig. 3. Diagram showing the decrease in nitrite in the water, increase in optical density and in plant pigments in diatoms contained in unit volume of culture, of Nitzschia in $75 \%$ sea water enriched with $3 \mathrm{mg}$. phosphate-P, $0.1 \mathrm{mg}$. iron, $0.02 \mathrm{mg}$. manganese and $2 \mathrm{mg}$. nitrate-N per litre (Exp. 8).

In $\operatorname{Exp} .8$ a culture was grown with a limiting concentration of nitrite. At intervals samples were removed whose nitrite concentration and optical density were determined. The optical density provides a measure of the cell numbers. In the method of determination used the relation was almost linear during the earlier growth, but towards the end of growth cell numbers increased slightly more quickly than the optical density increased. Samples were also separated by centrifuging and the cells' pigments extracted with 
boiling methanol. The yellow-green extracts were matched against a series of colour standards (Harvey, 1934; Riley, I94I). Since the tint was in all extracts a very exact match, the proportion of yellow pigments to chlorophyll in each was approximately the same.

The determinations (Fig. 3) show that pigment synthesis ceased after some $45 \mathrm{hr}$. illumination at about the time when all the nitrite in the medium had been utilized by the cells, which continued growth, making about one division thereafter.

After $\mathrm{I} 2 \mathrm{O} \mathrm{hr}$. illumination, samples of the culture were stored in darkness with and without the addition of nitrate. After $96 \mathrm{hr}$. dark storage the pigment content of the cells with added nitrate had increased by $70 \%$, while that of the cells without added nitrate remained the same.

At the conclusion of Exps. 3 and 4, (p. 478) plant pigments were determined in the cultures.

\begin{tabular}{|c|c|c|c|}
\hline \multirow{4}{*}{$\begin{array}{l}\quad \text { Addition } \\
\text { Exp. }{ }^{2} \\
\mathrm{NH}_{4}-\mathrm{N} \\
\mathrm{NO}_{3}-\mathrm{N} \\
\mathrm{NO}_{3}-\mathrm{N}+\mathrm{Na}_{2} \mathrm{~S}\end{array}$} & \multirow[b]{2}{*}{$\begin{array}{c}\text { Hours } \\
\text { dark } \\
\text { storage }\end{array}$} & \multicolumn{2}{|c|}{$\begin{array}{l}\text { Percentage increase after dark } \\
\text { storage due to the addition }\end{array}$} \\
\hline & & In $\mathrm{N}$ & $\begin{array}{c}\text { In plant } \\
\text { pigments }\end{array}$ \\
\hline & $\begin{array}{l}120 \\
120\end{array}$ & $\begin{array}{r}120 \\
85\end{array}$ & $\begin{array}{l}75 \\
50\end{array}$ \\
\hline & 120 & 60 & 25 \\
\hline Exp. 4 & 96 & 150 & 100 \\
\hline
\end{tabular}

A well-marked relation between synthesis of nitrogen and of plant pigments in the dark is apparent.

\section{Effect of Light Intensity on Chlorophyll Formation}

It is noticeable that when this diatom is grown in media containing an ample supply of available nitrogen and phosphorus, the cells are more pigmented after growth in dim than in bright light. Visual observations with other marine species suggest, however, that it is not light alone which controls pigment synthesis during growth in culture.

Several experiments were made employing the following methods of estimation.

Light intensity was measured with a photometer calibrated in terms of mean noon daylight. The diatom cultures were illuminated with white light from fluorescent lamps. This light differs from daylight in being composed of a number of wave-length bands dispersed throughout the spectrum, although it is similar in respect to the mean intensities of each spectral colour. Since the sensitivity of the photometer varies throughout the spectrum, determination of the intensity of this white light only approximates to the values recorded as mean noon daylight, since this has a different composition in detail. However, in terms of overall intensity or light energy the recorded values should be a 
good approximation. The greater light intensity used in the experiments (I2,000 lux) is similar to that in a north window on a moderately bright day.

Chlorophyll was measured either by determining the optical density of the yellow-green methyl alcohol extract in red light or with a spectro-photometer at the wave-length for maximum absorbtion near $655 \mu$.

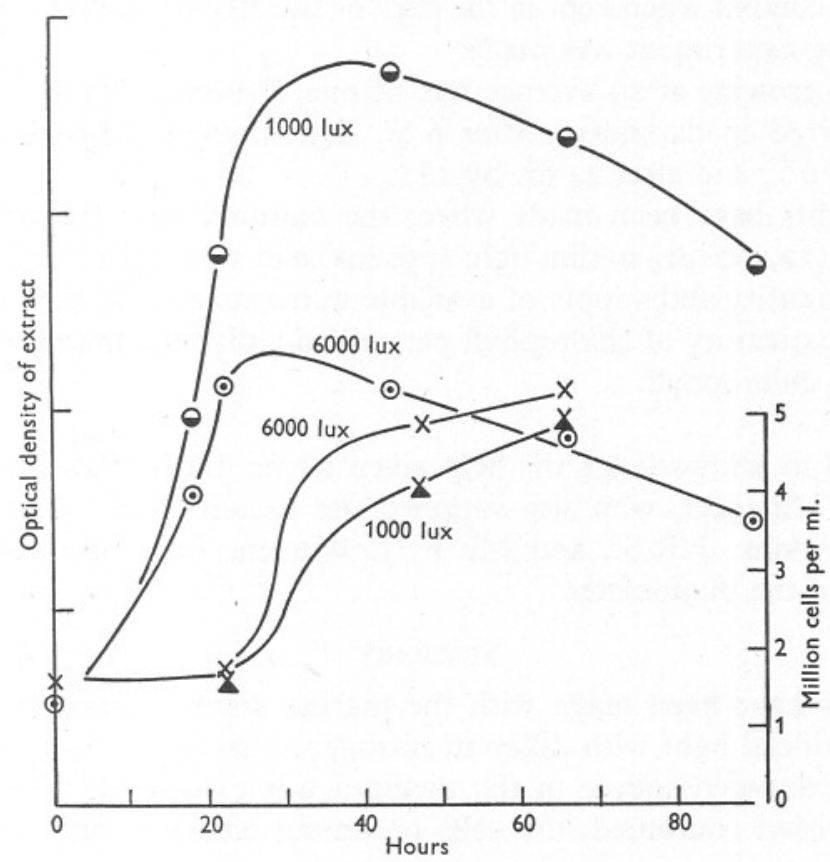

Fig. 4. Diagram showing chlorophyll formation and destruction in a culture with limiting supply of available nitrogen, illuminated at 1000 and at 6000 lux (Exp. 9).

In Exp. 9 sea water was diluted to $26 \%$ salinity and pasteurized, enriched with $3 \mu \mathrm{g}$. $/ \mathrm{ml}$. phosphate-P, $2 \mu \mathrm{g}$. ammonium-N per ml., iron and manganese, and was inseminated with Nitzschia, and divided into two Roux flasks.

One was illuminated at I000 lux and the other at 6000 lux.

The course of chlorophyll synthesis and proliferation of the cells is shown in Fig. 4. I am indebted to Dr C. P. Spencer for haemocytometer counts of the cell numbers.

The inseminum was an old culture, and over $24 \mathrm{hr}$. elapsed before cell numbers increased; meanwhile a considerable synthesis of chlorophyll had taken place.

After $45 \mathrm{hr}$. more than twice as much chlorophyll had been synthesized per cell in those illuminated at 1000 lux as in those at 6000 lux. 
Thereafter the chlorophyll in both cultures decreased, due to destruction by light, at a rate of half per cent per hour.

After $90 \mathrm{hr}$. illumination the cultures were stored in darkness for 6 days; no change in chlorophyll content occurred.

In order to find whether cells growing exponentially in moderate illumination in media rich in available nitrogen and phosphorus would increase their chlorophyll content when kept in the dark or transferred to dim illumination, the following experiment was made.

A culture growing at an average rate of one division in Io hr. in 8000 lux was transferred to darkness. After $6 \mathrm{hr}$. dark-storage chlorophyll had increased by $10 \%$ and after $24 \mathrm{hr}$. by $14 \%$.

Experiments have been made where the cultures were transferred from bright light (I2,000 lux) to dim light (750 lux) and vice versa. They indicated that light intensity and supply of available nutrients are not the only factors affecting the quantity of chlorophyll per cell and affecting the ratio of yellow pigments to chlorophyll.

I am glad to acknowledge the help given to me during these experiments by Dr C. P. Spencer, who also supplied the bacteria-free cultures. To Dr W. R. G. Atkins, F.R.S., and Mr F. J. Warren, I am also indebted for calibration of the photometer.

\section{SUMMARY}

Experiments have been made with the marine diatom Nitzschia closterium grown in artificial light with different nitrogen sources.

After the nitrogen source in the medium was exhausted, photosynthesis and cell division continued, the cells becoming nitrogen- and chlorophylldeficient.

On adding a nitrogen source to deficient cells and storing in darkness, synthesis of organic nitrogen, mostly water soluble, proceeded rapidly from ammonium, less rapidly from nitrate and very slowly from nitrite, with which it grows in light as rapidly as with nitrate or ammonium nitrogen.

Possible reasons why nitrate but not nitrite is reduced in the dark are discussed.

Chlorophyll and yellow pigments were synthesized in the dark by nitrogendeficient cells in quantity related to the organic nitrogen synthesized.

Chlorophyll was synthesized in small amount by non-deficient cells which had been growing rapidly before transfer to darkness.

Cells contained less chlorophyll when grown in moderately bright than when grown in dim light. 


\section{REFERENCES}

BonNer, J., I950. Plant Biochemistry. New York.

Burström, H., I946. The nitrate nutrition of plants. Ann. Roy. Agric. Coll. Sweden, Bd. I3, pp. I-86.

Conway, E. J., I940. Microdiffusion Analysis and Volumetric Error. New York.

Cramer, M. \& Myers, J., I948. Metabolic conditions in Chlorella. Fourn. Gen. Physiol., Vol. 32, pp. 92-IO2.

Harvey, H. W., I934. Measurement of phytoplankton population. Fourn. Mar. Biol. Assoc., Vol. 19, pp. 76I-73.

- 1940. Nitrogen and phosphorus required for the growth of phytoplankton. fourn. Mar. Biol. Assoc., Vol. 24, pp. II5-23.

1945. Recent Advances in the Chemistry and Biology of Sea Water. Cambridge University Press.

— I95I. Microdetermination of nitrogen in organic matter without distillation. Analyst, Vol. 76, pp. 657-60.

Ketchum, B. H., I939. The development and restoration of deficiencies in the phosphorus and nitrogen composition of unicellular plants. Fourn. Cell. Comp. Physiol., Vol. 13, pp. 373-8r.

Myers, J. \& Cramer, M., I948. Nitrate reduction and assimilation in Chlorella. fourn. Gen. Physiol., Vol. 32, pp. I03-I Iо.

RICKER, A. J. \& GUTSCHE, A. E., I948. The growth of sunflower gall tissue in vitro in synthetic media with various organic and inorganic sources of nitrogen. Amer. fourn. Bot., Vol. 35, pp. 227-38.

RILEy, G. A., I94I. Plankton studies. IV. Georges Bank. Bull. Bingham Oceanogr. Coll., Vol. 7 (4), pp. I-73. 